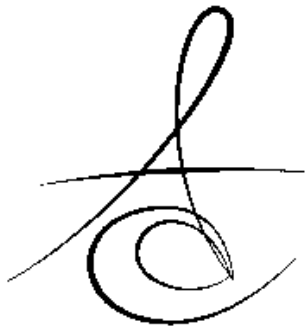

Makale Kodu/Article code: 1746

Makale Gönderilme tarihi: 19.06 .2014

Kabul Tarihi: 10.09.2014

\section{GUMMY SMILE TREATMENT WITH BOTULINUM TOXIN AND REVIEW OF LITERATURE- A CASE REPORT}

\section{BOTULİNUM TOKSİNLE GUMMY SMİLE TEDAVİSİ VE LİTERATÜR DERLEMESİ- OLGU SUNUMU}

\author{
Arş.Gör.Dt. Melike ÖZTÜRK* \\ Arş.Gör.Dt.Yerda ÖZKAN* \\ Prof.Dr.Recep ORBAK*
}

\section{ABSTRACT}

Aim: In this case report, Botulinum Toxin's application methods, advantages, disadvantages,

indications and contraindications are discussed at the literacy.

Case and Method: A 29-year-old woman came to our clinic with the complain of excessive gingival display on smiling. She was systemically healthy and she had no drug usage. $5 \mathrm{~mm}$ of gingival display

When smiling was diagnosed. After clinical examination, it was recorded that her gummy smile was due to hyperactive lip elevator muscles. Botulinum Toxin(Botox;Allergan Inc, Westport, Ireland) is applied according to manifacturer's instructions.

Results: After 1 week of the Botulinum Toxin injection the excessive gingival exposure is decreased $3.5 \mathrm{~mm}$ at the patient.

Conclusion: Gummy smile(GS) is an aesthetic disorder for some patients that is seen due to several factors which has some different treatment options such as orthognatic surgery, orthodontic treatment, gingivoplasty and bone resection. Latterly, Botulinum Toxin, is also being used at gummy smile cases as a minimal invasive treatment alternative to decrease excessive gingival display.

Keywords: Botulinum toxin,botox, gingival exposure, gummy smile

\section{INTRODUCTION}

Smile aesthetics is influenced by 3 factors: teeth, gums and lips. ${ }^{1,2}$ An aesthetical smile depends on those 3 components' proportions and arrangements. ${ }^{3}$ In a person with an attractive smile, the upper lip should symmetrically expose up to $3 \mathrm{~mm}$ of gum. ${ }^{1}$ If the exposure of gum is more than $3 \mathrm{~mm}$

\section{ÖZET}

Amaç: $\mathrm{Bu}$ olgu sunumunda, Botulinum Toksinin uygulama yöntemi, avantajları, dezavantajları, endikasyonları ve kontrendikasyonları literatür bilgileri ışığında incelenecektir.

Olgu ve Yöntem: 29 yaşında bayan hasta kliniğimize fazladan gingival görünüm şikayetiyle başvurdu. Hasta sistemik olarak sağlıklıydı ve herhangi bir ilaç kullanımı bulunmamaktaydı. Gülümseme esnasında hastada 5 $\mathrm{mm}$ dişeti görünümü tespit edildi. Klinik muayeneden sonra, gummy smile sebebinin hiperaktif elevator kaslar sebebiyle olduğu gözlendi. Botulinum Toksin(Botox;Allergan Inc. Westport, İrlanda) üreticinin talimatlarına göre uygulandı.

Bulgular: Botulinum Toksin enjeksiyonu sonrasında hastada gingival görünüm $3.5 \mathrm{~mm}$ azaldı.

Sonuç: Gummy smile(GS) birkaç neden ötürü görülen; ortognatik cerrahi, ortodontik tedavi, gingivoplasti ve kemik rezeksiyonu olmak üzere farklı tedavi seçenekleri mevcut olan estetik bir bozukluktur. Son zamanlarda, Botulinum Toksin gummy smile vakalarında minimal invaziv bir tedavi seçeneği olarak kullanılmaktadır.

Anahtar Kelimeler: Botulinum Toksin, botoks, gingival görünüm, gummy smile

* Atatürk Üniversitesi Diş Hekimliği Fakültesi Periodontoloji AD

during smile, this condition is called Gummy smile(GS). Gummy smile is one of several developmental or acquired deformities that is apparent in periodontium. ${ }^{4}$ It's prevalance at population is between $10.5 \%{ }^{5}$ and $29 \%{ }^{6}$ and it is more prevalent in females. $^{7}$

Gummy smile has several etiologic factors such as skeletal, gingival, muscular and their combination. ${ }^{8}$ 
Those factors include vertical maxillary excess, anterior dentoalveolar extrusion, altered passive eruption, short or hyperactive upper lip. ${ }^{9}$

Botulinum toxin has wide range of treatment conditions including strabismus, ${ }^{10}$ cervical dystonia, ${ }^{11}$ blepharospasm, ${ }^{10}$ hemifacial spasm, ${ }^{10}$ hyperfunctional larynx ${ }_{1}^{12}$ juvenile cerebral palsy, ${ }^{13}$ spasticity, ${ }^{14}$ pain and headache ${ }^{10}$ occupational dystonia and writer's ramp. ${ }^{15}$ In dentistry it can be used at temporomandibular disorders, ${ }^{16}$ myofacial and neck pain, ${ }^{16}$ oromandibular dystonia and bruxism, ${ }^{16}$ headache, migraine, trigeminal neuralgia, gummy smile, masseteric hypertrophy and

before dental implant surgeries for better osseo-ntegration. In this case report, we aimed to emphasize BTX-A injection,a minimal invasive treatment method on a patient with gummy smile.

\section{CASE REPORT}

A 29-year-old woman came to our clinic with the complain of excessive gingival display on smiling.

She was systemically healthy and she had no drug usage. $5 \mathrm{~mm}$ of gingival display on smiling was

diagnosed. After clinical examination, it was recorded that her gummy smile was due to hyperactive lip elevator muscles. BTX-A(Botox;Allergan Inc, Westport, Ireland) is applied as a freze-dried powder of $100 \mathrm{U}$,was reconstituted with $2 \mathrm{~mL}$ normal saline $(0.9 \%)$ solution to make $5.0 \mathrm{U} / 0.1 \mathrm{~mL}$ dose according to manifacturer's instructions. Injection sites were determined by muscle animation(smiling) and palpation to ensure to precise muscle location. The gingival display was reduced $3.5 \mathrm{~mm}$ after 1 week of injection. The patient is also advised not to lie down, do exercise, or massage the treated area during first 4 hours after procedure.

There are 4 different types of GS: 1)Anterior GS; more than $3 \mathrm{~mm}$ of gums are exposed between canine teeth,which involves the action of levator labii superioris alaeque nasi (LLSAN)muscles. 2)Posterior GS; in which more than $3 \mathrm{~mm}$ of gum is exposed posterior to canines, that involves the action of zygomatic muscles.3)Mixed GS; in both anterior and posterior there is excessive gingival display that involves two or more muscles' actions 4)Asymmetric GS; is ssen on one side that is caused by asymmetric contraction of LLSAN or zygomatic muscles.In our case, patient has anterior GS. Thus, the injection site is determined lateral to each nostril and $4 \mathrm{U}$ of Botox is injected. This provides vertical relaxation of upper lip but maintains the ability to smile and pout the lips. Another injection of BTX-A should be done after approximately 6 months.

Generally $1 \mathrm{ml}$ insulin syringes with removable 30 gauge needles are used for BTX-A injection. Those neeedles are not traumatic and does not cause any pain because of their size. Usually local anaesthesia is not necessary. There is still debate that if the skin should be prepared before injection or not. There are no evidence-based consensus on whether the skin should be disinfected with alcohol or chlorhexidine to prevent infection but this should be avoided due to the interaction between alcohol and BTX-A. ${ }^{17}$

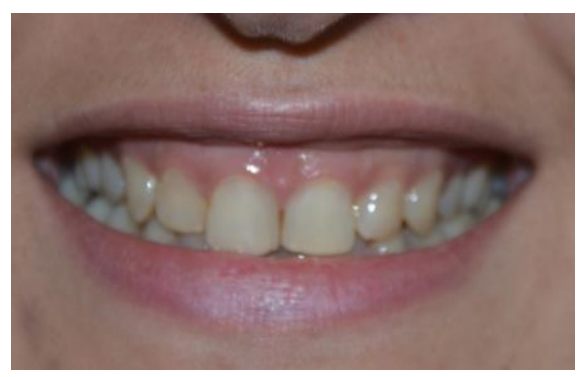

Picture 1. The clinical appearance of patient before Botox injection

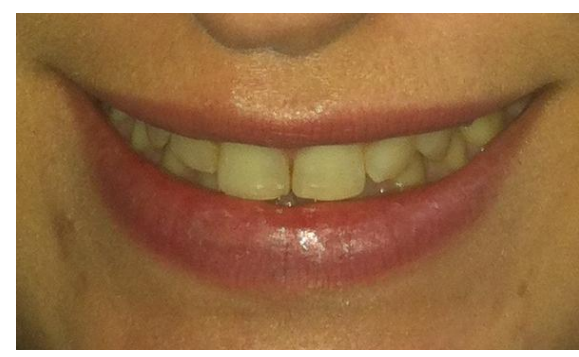

Picture 2. The clinical appearance of patient after 1 week of Botox injection

\section{DISCUSSION}

Gummy smile can be treated with orthognatic surgery, modified lip repositioning technique, crown lengthening. Recently Botulinum toxin injection has been started to use as a minimal invasive alternative.

If the etiologic factor is skeletal and patient is willing to have a surgery there are some different kinds of surgeries for GS. Rubinstein and Kostianovsky ${ }^{18}$ described a procedure in whic elliptical portion of gingiva and buccal mucosa is excised and

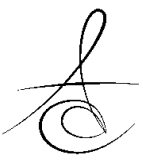


the approximated borders are sutured together. Litton and Fournier ${ }^{19}$ applied a treatment in which they bring the lip down by muscle detachment from the bony structures above. Silva et $\mathrm{al}^{20}$ investigated the modified lip repositioning technique at patients with gummy smile. Subjects were satisfied with the results but nevertheless they are surgical techniques and have some complications like limited morbidity and mucocele formation. ${ }^{21}$ Surgical procedures may result in frequent relapse and undesirable side effects such as scar contraction. BTX-A injection is less invasive than surgical techniques. Also, if it is not used in high amounts the adverse effects are seen very rarely. However, there are some adverse effects of BTX-A injection including infection, bruising, edema, loss of muscle strength,facial nerve palsy, dysphagia, hematoma and flu-like symptoms. Moreover, injection site should be carefully located.

Unless, asymmetric smile and inability to pucker can be seen. ${ }^{22}$ BTX-A has wide range of treatment options. On the other hand, in some cases its' usage is contraindicated. Administration of BTX-A should be avoided during pregnancy, breast-feeding, patients with neuromuscular junction isorders (Myasthania gravis,Lambert-Eaton syndrome) and neurodegenerative diseases(amyotrophic lateral sclerosis). Due to the effection of aminoglycoside antibiotics to BTX-A, its appyling should be avoided. Furthermore, BTX-A may have drug interactions with calcium channel blockers, cyclosporine and cholinesterase inhibitors.

Another point that should be careful is not to administer high frequent of BTX-A(more than 12 weeks) because repeated exposure can result in formation of neutralizing antibodies against the toxin that can lead to disappointing results. ${ }^{23}$

The dosage of BTX-A injection is very prerequisite. Between females and males, the dosage is different relating to muscle volume. In general, males have a larger muscle volume and require more units of BTX-A to achieve the same results as female patients. ${ }^{24}$ The injection dose differs among studies. Polo applied multiple injection into each elevator muscle with doses ranging from $0.625 \mathrm{U}$ to $2.5 \mathrm{U}$ at different phases. ${ }^{25}$ Garcia found tht 2 to $5 \mathrm{U}$ of BTX-A is effective as higher doses. ${ }^{26}$ High dosages of applyment of BTX-A injection should be avoided because of side effects. The lethal dose of Botox in humans is not known but it has been estimated nearly $3000 \mathrm{U}^{27}$

For getting the best results, BTX-A should be kept according to the manufacturer's instructions. Once opened, the drug must be stored at temperature of $2-8^{\circ} \mathrm{C}$. Also, it should be used within $4-8$ hours. Those recommendations are for sterility and efficacy of drug. However, in some studies it has shown that toxin's efficacy remains same until 15 days after reconstitution and no bacterial contamination occurs. ${ }^{28}$

Despite of some adverse effects and reversibility of BTX-A via regeneration of nerve-muscle complex and SNAP-25 proteins, BTX-A injections seems to be the least invasive treatment option for gummy smile cases.

\section{CONCLUSION}

Botulinum toxin has been popular and has been started to be investigated extensively at dentistry for several cases. It is more preferred from patients with gummy smile due to the minimal invasiveness.

However, dentists should start to apply BTX-A injection at perioral area after a detailed education programme to avoid adverse effects and malpractise cases.

\section{REFERENCES}

1. Garber DA, Salama MA. The aesthetic smile: diagnosis and treatment. Periodontol 2000 1996;11: 18-28.

2. Gill DS, Naini FB, Tredwin CJ. Smile aesthetics. SADJ 2008; 63:272-5

3. Davis NC. Smile design. Dent Clin North Am 2007; 51:299-318.

4. Armitage, GC. Development of a classification system for periodontal disease and conditions. Annals of Periodontology 1999; 4: 1-6.

5. Tjan AH, Miller, GD,The JG. Some esthetic factors in a smile. The Journal of Prosthetic Dentistry 1984; 51: 24-8.

6. Dong, JK, Jin TH, Cho, HW. Oh, SC. The esthetics of the smile: a review of some recent studies. International JProsthodontics 1999; 12: 9-19.

7. Peck, S., Peck, L. \& Kataja, M. The gingival smile line. The Angle Orthodontist 1992; 62: 91-100.

8. Ezquerra F, Berrazueta MJ, Ruiz-Capillas A, Arregui JS. New approach to the gummy smile. Plast

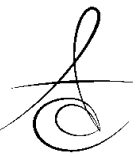


Reconstr Surg 1999; 104: 1143-50.

9. Silberberg N, Goldstein M, Smidt A. Excessive gingival display-etiology, diagnosis, and treatment modalities. Quintessence Int 2009; 40: 809-18.

10. Brin MF, Hallett M, Jankovic J. Preface. In: Brin MF, Hallet $M$, Jankovic J, editors. Scientific and therapeutic aspects of botulinum toxin. Philadelphia: Lippincott Williams and Wilkins; 2002. p. 223-32 .

11. Comella CL. Cervical dystonia: treatment with botulinum toxin serotype $A$ as Botox $\AA$ or Dysport $\AA$. In: Brin MF, Hallet M, Jankovic J, editors. Scientific and therapeutic aspects of botulinum toxin. Philadelphia: Lippincott Williams and Wilkins; 2002. p. 359-64.

12. Blitzer A, Zalvan C, Gonzalez-Yanez O, Brin MF. Botulinum toxin type $A$ injections for the management of the hyperfunctional larynx. In: Brin MF, Hallet M, Jankovic J, editors. Scientific and therapeutic aspects of botulinum toxin. Philadelphia: Lippincott Williams and Wilkins; 2002. p. 207-16.

13. Delgado MR. The use of botulinum toxin in juvenile cerebral palsy. In: Brin MF, Hallet M, Jankovic J, editors. Scientific and therapeutic aspects of botulinum toxin. Philadelphia: Lippincott Williams and Wilkins; 2002. p. 217-22.

14. Moore AP. Botulinum toxin type $A$ in the treatment of spasticity. In: Brin MF, Hallet M, Jankovic J, editors. Scientific and therapeutic aspects of botulinum toxin. Philadelphia: Lippincott Williams and Wilkins; 2002. p. 223-32.

15. Karp BI. The role of botulinum toxin type A in the management of occupational dystonia and writer's cramp. In: Brin MF, Hallet M, Jankovic J, editors. Scientific and therapeutic aspects of botulinum toxin. Philadelphia: Lippincott Williams and Wilkins; 2002. p. 251-8.

16. Schwartz $M$, Freund B. Botulinum toxin A therapy for temporomandibular disorders. In: Brin MF, Hallet M, Jankovic J, editors. Scientific and therapeutic aspects of botulinum toxin. Philadelphia: Lippincott Williams and Wilkins; 2002. p. 259.

17. Gadhia K, Walmsley AD. Facial aesthetics: is botulinumtoxin treatment effective and safe? A systematic review of randomized controlled trials. $\mathrm{Br}$ Dent J 2009: 207: 1-9.

18. Rubinstein $A$, Kostianovsky $A$. Cosmetic surgery for the malformation of the laugh: original technique. Prensa Med Argent 1973;60:952.
19. Litton C, Fournier P. Simple surgical correction of the gummy smile. Plast Reconstr Surg 1979; 63: 372-3.

20. Silva CO, Ribeiro-Junior NV, Campos TVS, Rodrigues JG, Tatakis DN. Excessive gingival display: treatment by a modified lip repositioning technique. J Clin Periodontol 2013; 40: 260-5. doi: 10.1111/ jcpe. 12046.

21. Simon Z, Rosemblatt A, Dorfmann W. Eliminating a gummy smile with surgical lip repositioning. J Cosmetic Dent 2007; 23: 100-8.

22. Niamtu III J. Botox injections for gummy smiles. Am J Orthod Dentofacial Orthop 2008: 133: 782-3.

23. Borodic G. Immunologic resistance after repeated botulinum toxin type a injections for facial rhytides. Ophthal Plast Reconstr Surg 2006: 22: 239-40.

24. Carruthers A, Carruthers J, Flynn TC, Leong MS. Dose-finding, safety, and tolerability study of botulinum toxin type $B$ for the treatment of hyperfunctional glabellar lines. Dermatol Surg 2007; 33: S60-8.

25. Polo M. Botulinum toxin type $A$ in the treatment of excessive gingival display. Am J Orthod Dentofacial Orthop 2005;127: 214-8; quiz 261.

26. Garcia A, Fulton JE Jr. Cosmetic denervation of the muscles of facial expression with botulinum toxin: a dose-response study. Dermatol Surg 1996; 22: 3943.

27. Katz $\mathrm{H}$, Blumenfeld A. Can Botulinum toxin A (BOTOX) save your teeth and enhance your smile? Available from: http://sci.tech-archive.net/ Archive /sci.med. dentistry/2004-06/0484.html. [last cited on 2009].

28. Hexsel D, Rutowitsch MS, de Castro LC, do Prado DZ, Lima MM. Blind multicenter study of the efficacy and safety of injections of a commercial preparation of botulinum toxin type $A$ reconstituted up to 15 days before injection. Dermatol Surg 2009: 35: 9339.

\author{
Yazışma Adresi \\ Dt. Melike ÖZTÜRK \\ Atatürk Üni. Diş Hek. Fak. \\ Periodontoloji Anabilim Dalı \\ Yakutiye -ERZURUM \\ e-mail : dtmelikeozturk@hotmail.com
}

